\title{
Farm Management Effects on Rhizosphere Colonization by Native Populations of 2,4-Diacetylphloroglucinol-Producing Pseudomonas spp. and Their Contributions to Crop Health
}

\author{
Dorith Rotenberg, Raghavendra Joshi, Maria-Soledad Benitez, Laura Gutierrez Chapin, Amara Camp, Clara Zumpetta, \\ Adam Osborne, Warren A. Dick, and Brian B. McSpadden Gardener
}

Department of Plant Pathology, The Ohio State University, OARDC, Wooster 44691.

Accepted for publication 9 December 2006.

\begin{abstract}
Rotenberg, D., Joshi, R., Benitez, M.-S., Gutierrez Chapin, L., Camp, A., Zumpetta, C., Osborne, A., Dick, W. A., and McSpadden Gardener, B. B. 2007. Farm management effects on rhizosphere colonization by native populations of 2,4-diacetylphloroglucinol-producing Pseudomonas spp. and their contributions to crop health. Phytopathology 97:756-766.

Analyses of multiple field experiments indicated that the incidence and relative abundance of root-colonizing phlD+ Pseudomonas spp. were influenced by crop rotation, tillage, organic amendments, and chemical seed treatments in subtle but reproducible ways. In no-till corn plots, 2year rotations with soybean resulted in plants with approximately twofold fewer phlD+ pseudomonads per gram of root, but 3-year rotations with oat and hay led to population increases of the same magnitude. Interestingly, tillage inverted these observed effects of cropping sequence in two consecutive growing seasons, indicating a complex but reproducible interaction between rotation and tillage on the rhizosphere abundance of 2,4-diacetlyphloroglucinol (DAPG) producers. Amending conventionally managed sweet corn plots with dairy manure compost improved plant

pared with nonamended plots. Soil $\mathrm{pH}$ was negatively correlated to rhizosphere abundance of phlD+ pseudomonads in no-till and nonamended soils, with the exception of the continuous corn treatments. Chemical seed treatments intended to control fungal pathogens and insect pests on corn also led to more abundant populations of phlD in different tilled soils. However, increased root disease severity generally was associated with elevated levels of root colonization by $p h l D+$ pseudomonads in notill plots. Interestingly, within a cropping sequence treatment, correlations between the relative abundance of phlD and crop stand or yield were generally positive on corn, and the strength of those correlations was greater in plots experiencing more root disease pressure. In contrast, such correlations were generally negative in soybean, a difference that may be partially explained by difference in application of $\mathrm{N}$ fertilizers and soil $\mathrm{pH}$. Our findings indicate that farming practices can alter the relative abundance and incidence of $p h l D+$ pseudomonads in the rhizosphere and that practices that reduce root disease severity (i.e., rotation, tillage, and chemical seed treatment) are not universally linked to increased root colonization by DAPG-producers.
\end{abstract} health and also increased the incidence of root colonization when com-
Diverse microbes have the capacity to inhibit the growth and activities of various soilborne plant pathogens (48). However, the contribution of specific native populations to disease suppression remains a mystery. Pseudomonas spp. that produce the antibiotic 2,4-diacetlyphloroglucinol (DAPG) have the capacity to suppress diverse soilborne plant pathogens, and they have been hypothesized to contribute to specific disease suppression in different soils (47). Although DAPG producers are known to inhabit agricultural soils throughout the world, the phlD gene, which is essential for DAPG production, has been used to detect DAPG producers in the rhizosphere of different crop plants $(17,27,33,46)$. However, their relative abundance has been assessed in only a few instances. Early work suggested that DAPG producers were more abundant in one set of root disease-suppressive soils (i.e., take-all decline soils) $(34,35)$. Later work showed similar patterns in the Netherlands (9). DAPG producers also are abundant in Morens soils suppressive to tobacco black rot. However, in those soils, rhizosphere abundance failed to directly correlate with root disease suppression (36). The roots of field-grown corn and soybean plants frequently are colonized by substantial populations of DAPG producers (28). Because the abundance of these popula-

Corresponding author: B. B. McSpadden Gardener;

E-mail address: bbmg+@osu.edu

doi:10.1094/PHYTO-97-6-0756

(C) 2007 The American Phytopathological Society tions frequently exceeded $\log 4.5$ cells per gram of root tissue, a threshold level previously associated with root disease suppression $(9,34)$, we hypothesized that native populations of these bacteria generally may contribute to the health and productivity of these two crops under typical growing conditions.

Managed and unmanaged environmental variables can significantly affect crop health and the microbial populations that impact it $(18,20)$. Practices such as tillage, crop rotation, and the use of organic amendments have been shown to alter soil physical, chemical, and biological properties that can directly or indirectly influence soilborne pathogen survival and infection of host crops (41). In general, the practice of tillage breaks up surface crop residues and disturbs fungal pathogen networks, events which have been linked to reduced incidence of soilborne diseases caused by residue-colonizing pathogens (2,5). Crop rotation sequences likely impart their effect on soilborne pathogens by reducing the availability of the preferred food source (the host) and thereby reducing inoculum levels. However, rotation also can result in changes in soil moisture, temperature, and soil chemistries based on the quantity and quality of residue and how it is managed. These changes also likely affect pathogen suppression, which is known to be a substrate-dependent phenomenon (16). Additions of composted organic amendments to field soils have been shown to reduce severity of soilborne diseases $(22,42)$ and the efficacy of a particular compost amendment is mediated by the complex interactions between biotic and abiotic soil factors. Although these management practices can significantly improve crop health and 
productivity, their utility is unpredictably limited due to the diverse environmental conditions and soil types encountered in agricultural systems.

The phlD gene encodes a polyketide synthase that is essential for the production of DAPG (3). Gene-specific primers have been developed $(26,35)$ and used to identify, isolate, and characterize DAPG-producing pseudomonads by colony hybridization $(8,23$, $27,33,35,45)$ and end-point dilution polymerase chain reaction (PCR) $(26,28)$. Here, we used the latter approach to characterize the influence of different farm management practices on the abundance of DAPG producers in the rhizosphere of field-grown corn and soybean plants.

Seed treated with DAPG-producing pseudomonads, alone and in combination with chemical fungicides, have been shown repeatedly to increase the health and productivity of field crops. On wheat, stands and yields can be increased by the use of bacterial seed treatments containing phlD+ pseudomonads (6). In addition, genetic modification of strains to increase DAPG production can further enhance soilborne disease suppression in different crops $(7,44)$. Our own experience with corn and soybean indicates that seed inoculated with phlD+ pseudomonads generally leads to higher stands and yields $(24,25,28$, unpublished results). Thus, when present in abundance and given preferred access to the growing root, the net effect of DAPG producers on plant health is generally positive, especially in the presence of soilborne disease pressure. Because of this, we hypothesized that, over some measurable range, increases in rhizosphere abundance of DAPG producers would result in concomitant improvements in crop health, assuming that the benefit to plant health would increase on a per-cell basis. If such a phenomenon generally occurs, then a positive correlation between crop health and the abundance of DAPG producers would exist. However, we also hypothesized that interactions with the plant host and environment might alter this relationship, making the net association context dependent. In this study, our objectives were to (i) characterize the responses of native, rhizosphere populations of phlD+ Pseudomonas spp. to different farm practices, (ii) determine the correlation between rhizosphere abundance of phlD and soil chemistry, and (iii) characterize the quantitative association between the relative abundance of root-colonizing phlD+ pseudomonads and crop health, as indicated by stands and yields.

\section{MATERIALS AND METHODS}

Site description and sampling schedule. Young corn and soybean root samples were collected in 2004 and 2005 from established research field sites located at the Ohio Agricultural Research and Development Center, Wooster. The research sites were a long-term tillage and rotation site (LTT), a corn-soybean rotation site managed under no-tillage (ROTA), and a conventionally managed sweet corn and compost site (SCC). The predominant soil type at these sites is Wooster silt loam. Plots were seeded in late April (corn) and early May (soybean). Additionally, a series of seed treatment trials (STT) were conducted at multiple field sites throughout Ohio.

The LTT site, established in 1962, has experienced $>40$ years of continuous management and has been used to investigate the combined effect of tillage and rotation on corn stands and yields (10). The experimental design is a factorial with three tillage treatments: conventional tillage (PT) (moldboard plowing), moderate tillage (MT) (chisel plowing), and no-tillage (NT); and three rotation treatments: continuous corn (CCC), 2-year corn-soybean (CSC), and 3-year corn-oat-hay $(\mathrm{COH})$. Each tillage-rotation combination was assigned to 22.3-by-4.3-m plots and replicated three times. Fungicide-treated corn seed were planted to six rows at $0.76-\mathrm{m}$ spacing. In all, 27 plants were sampled (one plant $\times$ three subplots $\times$ three tillage $\times$ three rotations) on 13 July 2004 and again on 30 June 2005.
The ROTA site was established in 2001 to determine the midterm effects of corn-soybean rotation sequences on rhizosphere abundance of DAPG producers on corn and soybean under no-till management. The experimental design was a randomized complete block $(n=4)$ with four rotation treatments: (i) continuous corn (CC), (ii) corn following a soybean season (SC), soybean following a corn season (CS), and (iv) continuous soybean (SS). Each plot was 6.1 by $16.7 \mathrm{~m}$; corn and soybean plots consisted of eight rows at 0.76 -in. spacing and 15 rows at $0.38-\mathrm{m}$ spacing, respectively. Untreated (no fungicide) seed corn hybrid SC1091 (Seed Consultants, Inc., Washington Courthouse, OH) and soybean cv. Kottman (Grier Seed Farms, Fremont, OH) were used each year. The two elite cultivars were selected on the basis of their high yield potential and high degree of resistance to soilborne root diseases. Corn plots received $\mathrm{N}$ at $181 \mathrm{~kg} \mathrm{ha}^{-1} 2$ weeks prior to planting whereas soybean plots received no $\mathrm{N}$ fertilizer. One plant was sampled on 24 May (V1) and 9 June (V3) in 2004 and two plants were sampled on 6 June (V4) and 1 July (V6) in 2005 from each subplot. Thus, a total of 32 plants were sampled in 2004 (one plant $\times$ two growth stages $\times$ four subplots $\times$ two crops $\times$ two rotations), and 64 plants were sampled in 2005 (two plants per growth stage).

The SCC field site was established in 2003 and sampled in 2004 to determine the effect of adding dairy manure or sawdust compost on native rhizosphere populations of phlD+ pseudomonads and sweet corn health. The experimental design was a factorial with three sweet corn cultivars (Bodacious, Ambrosia, and Kandy Korn) (Holmes Seed Co., Canton, $\mathrm{OH}$ ) and three compost rates $\left(0,6\right.$, and $\left.12 \mathrm{tha}^{-1}\right)$. Plot dimensions were 5.3 by $6.1 \mathrm{~m}$ and consisted of eight rows of fungicide-treated seed at $0.76-\mathrm{m}$ spacing. The compost was produced at the OARDC on-site composting facility and the chemical and physical characteristics of the mature compost are described elsewhere (46). Compost was applied to plots and incorporated in the spring, 2 weeks prior to planting fungicide-treated seed in April of 2003 and 2004. In 2004 , one root was sampled on 26 May (V2) from plots containing Ambrosia and Bodacious and on 2 June (V4) from plots cropped to Ambrosia and Kandy Korn. In all, 36 plants were sampled in 2004 (one plant $\times$ two growth stages $\times$ three subplots $\times$ two cultivars/sampling $\times$ three treatments).

The STT sites were planted adjacent to the Ohio State University Corn Performance Trials in 2004. This experiment compared untreated corn seed, hybrid SC1091 (Seed Consultants, Inc., Washington Courthouse, $\mathrm{OH}$ ), to seed from the same lot treated with a combination of Maxim (a fungicide) and Lorsban (an insecticide) prior to purchase. Trials were conducted in Clark, Crawford, Darke, Wood, and Wyandot Counties on high-fertility silt-loam soils, with each site receiving $\mathrm{N}$ at between 200 and $250 \mathrm{~kg} \mathrm{ha}^{-1}$ as well as variable amounts of $\mathrm{P}$ and $\mathrm{K}$ fertilizers in excess of crop needs at each location. Each plot was 3.0 by $7.5 \mathrm{~m}$. Each trial was set up in a replicated block design with four replicates each, and plants were sampled between V3 and V5 at each location. In total, 40 plants were sampled in 2005 (one plant $\times$ four subplots $\times$ two treatments $\times$ five sites).

Crop measurements. Plant stand counts were recorded for each plot to estimate the amount of damping-off disease at time of plant sampling. In the LTT and STT studies, the total number of emerged plants was determined once in each corn plot in early June of each year. In the ROTA and SCC study, plant stand was determined at the time of plant sampling at multiple, randomly chosen 1-m row segments within each plot. The number of plants spanning both sides of 16 corn and 8 soybean row segments was recorded and an average stand count was calculated for each ROTA plot. In a similar fashion, 8 stand counts were recorded for each plot planted to cvs. Ambrosia and Bodacious and 16 stand counts were recorded for cvs. Ambrosia and Kandy Korn in the SCC study. Crop yields were measured at harvest in October of each field season and reported at 15 and $13.5 \%$ seed moisture 
levels for corn and soybean, respectively. In the LTT and FTT plots, harvests of the middle two rows were used to calculate yield. In the ROTA experiments, the middle four and eight rows of each corn and soybean plot, respectively, were used to calculate total yields. Harvested yield was not measured in the SCC trial.

Soil testing. Soil samples were submitted to the OARDC's Soil Testing and Research (STAR) lab for analysis. Water $\mathrm{pH}$ was measured according to standard procedures (43). Total carbon and nitrogen were assessed using a VarioMax carbon-nitrogen combustion analyzer (Elementar America Inc., Mt. Laurel, NJ). For mineral nutrients, soil extractions were performed following the procedures of Helmke and Sparks (14) and quantities determined using a Prodigy Dual View inductively coupled plasma spectrophotometer (Teledyne Leeman Labs). Additionally, volumetric soil moisture content was assessed on site at the time of sampling for the ROTA and SCC trials, using a Field Scout TDR100 soil moisture meter (Spectrum Technologies, Plainfield, IL).

Processing of rhizosphere samples and enumeration of phlD+ pseudomonads. The abundance and diversity of culturable and phlD-containing Pseudomonas spp. in the rhizosphere were determined using the PCR-based assay described previously (26) with slight modifications. Briefly, roughly equal-sized portions of individual seedling root systems ( 1 to $2 \mathrm{~g}$ fresh weight) were recovered individually from the soil, separated from the shoot, and placed in $15 \mathrm{ml}$ of sterile distilled water. Bacteria were dislodged from the roots by vortexing and sonication (1 min each) prior to serial dilution $(1: 3.5)$ in a 96-well plate prefilled with sterile deionized water. From these "rhizosphere-wash" plates, $50 \mu \mathrm{l}$ of each dilution was transferred into other 96-well plates containing $200 \mu \mathrm{l}$ of a Pseudomonas selective medium, .33× King's Medium $\mathrm{B}$ amended with ampicillin at $40 \mathrm{ppm}$, chloramphenicol at $12.5 \mathrm{ppm}$, and cycloheximide at $100 \mathrm{ppm}$. Culture plates were incubated for 2 days at room temperature and bacterial growth was assayed spectrophotometrically (ELx800 microplate spectrophotometer; Bio-Tek Instruments, Winooski, VT). The terminal dilution displaying bacterial growth (optical density at $595 \mathrm{~nm} \geq$ 0.1 ) was used to calculate the relative abundance of Pseudomonas spp. Cultures were frozen for storage prior to use as whole-cell DNA templates. Portions of the phlD gene were amplified using the gene-specific primers B2BF and BPR4 (26) in a PTC-200 thermal cycler (MJ Research, Watertown, MA). Reaction products were separated on $1.5 \%$ agarose gels in $0.5 \times$ Tris-borate-EDTA buffer and visualized by ethidium bromide staining. Gel images were processed using a Kodak EDAS 290 digital imaging system (Kodak, Rochester, NY). Enumerations were based on the endpoint dilution method. Incidence of positive phlD amplifications were used to calculate incidence of root colonization on a pergram fresh weight basis. Because the relative abundance of phlD+ pseudomonads cannot be accurately determined below the limit of detection, average abundance and all correlation analyses were performed using data from only those samples that harbored at least log 3.5 cells per gram fresh weight of root tissue.

Statistical analyses. Both parametric and nonparametric statistical tests were performed to make inference about treatment effects (i.e., farm management practices) on Pseudomonas populations, crop health, and soil properties. All tests were performed with SAS (v9.1; SAS Institute, Inc., Cary, NC) unless otherwise noted. Analysis of variance was conducted on abundance of total and phlD+ pseudomonads ( $\log _{10} \mathrm{CFU} \mathrm{\textrm {g } ^ { - 1 }}$ of root), proportion of pseudomonads composed of phlD+ bacteria (arcsine square-roottransformed values), average plant stand per plot, crop yield, and soil properties (volumetric moisture [VM], soil $\mathrm{pH}$, soil $\mathrm{C}$ and $\mathrm{N}$, and soil macro- and micronutrient contents) using PROC MIXED. The LSMEANS statement was used to calculate least square differences and to make comparisons between treatments. Fisher's exact test was performed to determine if the proportion of roots colonized by phlD+ bacteria was independent of treatment.
Because each experiment differed somewhat in design and replication, different statistical models were applied in the analyses of each. For the LTT experiment, a factorial model was tested on the two main effect treatments (rotation sequence and tillage practice) and the interaction between them. For the ROTA experiment, a factorial model including two main effects, rotation treatment and plant age at time of sampling (V stage), and their interaction was tested to determine whether abundance or incidence of phlD+ bacteria within Pseudomonas populations varied with plant age. An average abundance and percent phlD+ value was obtained for each pair of root samples taken at each time point from each plot prior to analysis. Because treatment trends were found to be similar for the two $\mathrm{V}$ stages, population data were pooled for each rotation treatment and analyzed using a GLM model to verify rotation effects on these variables. Stand and yield data for corn and soybean were analyzed separately in this study. For the SCC experiment, a factorial model was tested on two main effects, compost treatment and cultivar, and their possible interactive effects on total Pseudomonas populations and plant stand at each V stage. Differences in abundance of phlD+ bacteria between sweet corn cultivars were compared using Mann-Whitney test statistics (MINITAB v.13.31; Minitab, Inc., State College, PA) for each compost treatment because of the limited sample size after removal of values considered below the limit of detection. Because there was no apparent effect of cultivar on stand or rhizosphere abundance for each compost treatment $(P>0.25)$, data from the three cultivars were pooled at each time point prior to analysis of compost treatment means.

Correlation analyses of abundance and crop health (i.e., stand and yield) or soil chemistries were performed on a per-treatment basis. Paired comparisons of rhizosphere abundance, incidence of phlD+ bacteria, stand, yield, and soil variables were made to determine whether crop health or soil factors were associated with rhizosphere colonization under the different farm management strategies. Pearson correlation coefficients $(r)$ were calculated for each relationship (MINITAB v.13.31).

\section{RESULTS}

Rhizosphere abundance of phlD+ pseudomonads in LTT corn plots. Corn plants were sampled from LTT plots to determine the combined effects of differential tillage and crop rotations on the natural abundance of phlD-containing Pseudomonas populations in the rhizosphere (Table 1). Differences in tillage led to the most consistent responses in root colonization by phlD + pseudomonads. Average abundance of these bacteria differed significantly among several treatments in $2005(P=$ 0.019). The incidence of roots colonized at high population levels was significantly influenced by tillage. Overall, the incidence of roots colonized by populations exceeding log 4.5 cells per gram fresh weight of root was significantly lower in the moderately tilled plots in $2004(P=0.02)$ and $2005(P=0.04)$ compared with the no-till and plow-till plots. This effect was noticeable in all three rotation treatments in 2004, and in two of the three rotations in 2005. The exception was the CSC rotation in 2005 because no phlD+ pseudomonads were detected in the no-till treatment plots of that particular rotation. The effect of cropping sequence in these plots varied between the 2 years. In 2004, rotation apparently increased the proportion of roots colonized by high populations of phlD-containing pseudomonads $(P=0.07)$ compared with roots grown in CC plots, but the pattern was reversed $(P=$ 0.04 ) in 2005. Interestingly, the interactions between tillage practice and cropping sequence influenced the abundance of rootassociated phlD+ bacteria, and the patterns of the interaction were very similar for both the 2004 and 2005 samplings (Fig. 1). In the NT plots, the lowest colonization levels were observed in the 2-year rotation treatments. In contrast, soil disturbance in the MT and PT plots led to relatively higher levels of colonization in 
the CSC plots compared with the other rotations. Although this pattern of interaction was not significant in 2004, it was in 2005 $(P=0.02)$.

Rhizosphere abundance of phlD+ pseudomonads in ROTA plots. To further explore the influence of cropping sequence on native populations of $p h l D+$ pseudomonads, young plants (V1 to V4) were sampled from corn and soybean rotation plots that had not experienced any tillage for 4 years. Under these conditions, rotation sequence had no apparent effect on the abundance of Pseudomonas populations or phlD+ bacteria per gram of corn $(P$ $>0.25)$ or soybean root $(P>0.25)$ in either year. Nonetheless, the average phlD+ populations and the proportion thereof tended to be higher on plants grown in plots previously cropped to corn
(Table 2). The percentage of Pseudomonas spp. likely capable of producing DAPG was greater $(P<0.05)$ on soybean following corn than soybean in 2004. Unique to 2004, plant age influenced the relative abundance of phlD+ pseudomonads associated with the corn-soybean rotation treatments. The V1-stage roots supported 0.7 to $1 \log$ more cells of phlD+ bacteria per gram than the V3-stage roots in the rhizosphere of corn and soybean for all treatments $(P=0.001$ to 0.04$)$. It is important to note that all the corn plants had reached the V2 stage at the first sampling in 2005 and, therefore, V1 corn samples were not included in the analysis.

In this experiment, rhizosphere abundance of $p h l D+$ bacteria was significantly correlated with several soil properties (Table 3 ). The average abundance of phlD+ bacteria on both corn and soy-

TABLE 1. Effect of rotation sequence and tillage practice on corn yields and phlD+ pseudomonads in the long-term tillage plots located in Wayne County, Ohio ${ }^{\mathrm{u}}$

\begin{tabular}{|c|c|c|c|c|c|c|}
\hline \multirow[b]{2}{*}{ Year, rotation $^{\mathrm{w}}$} & \multirow[b]{2}{*}{ Tillage $^{\mathrm{x}}$} & \multirow[b]{2}{*}{ Abundance ${ }^{y}$} & \multicolumn{2}{|c|}{ Incidence $^{\mathrm{v}}$} & \multirow[b]{2}{*}{ Stand (plants $\mathrm{m}^{-1}$ ) } & \multirow[b]{2}{*}{ Yield $\left(\mathrm{t} \mathrm{ha}^{-1}\right)$} \\
\hline & & & $\geq \log 4.5$ & $\geq \log 3.5$ & & \\
\hline \multicolumn{7}{|l|}{2004} \\
\hline $\mathrm{CCC}$ & PT & $4.8 \mathrm{a}$ & 0.67 & 0.67 & $5.4 \mathrm{a}$ & $9.8 \mathrm{~b}$ \\
\hline $\mathrm{CCC}$ & MT & $3.8 \mathrm{a}$ & 0.00 & 1.00 & $5.3 \mathrm{a}$ & $9.1 \mathrm{~b}$ \\
\hline $\mathrm{CCC}$ & NT & $4.5 \mathrm{a}$ & 0.33 & 0.67 & $4.7 \mathrm{a}$ & $10.7 \mathrm{ab}$ \\
\hline $\mathrm{CSC}$ & PT & $4.7 \mathrm{a}$ & 0.67 & 1.00 & $5.1 \mathrm{a}$ & $10.4 \mathrm{ab}$ \\
\hline CSC & MT & $4.6 \mathrm{a}$ & $0.50^{\mathrm{z}}$ & 1.00 & $4.7 \mathrm{a}$ & $12.6 \mathrm{a}$ \\
\hline $\mathrm{CSC}$ & NT & $4.1 \mathrm{a}$ & 0.67 & 0.67 & $4.5 \mathrm{a}$ & $8.8 \mathrm{cb}$ \\
\hline $\mathrm{COH}$ & PT & $4.5 \mathrm{a}$ & 0.67 & 1.00 & $5.3 \mathrm{a}$ & $10.8 \mathrm{ab}$ \\
\hline $\mathrm{COH}$ & MT & $4.2 \mathrm{a}$ & 0.00 & 0.50 & $5.1 \mathrm{a}$ & $10.6 \mathrm{ab}$ \\
\hline $\mathrm{COH}$ & NT & $4.9 \mathrm{a}$ & 1.00 & 1.00 & $5.3 \mathrm{a}$ & $10.8 \mathrm{ab}$ \\
\hline \multicolumn{7}{|l|}{2005} \\
\hline $\mathrm{CCC}$ & PT & $4.7 \mathrm{ab}$ & 0.67 & 1.00 & $5.3 \mathrm{ab}$ & $5.7 \mathrm{~d}$ \\
\hline $\mathrm{CCC}$ & MT & $4.6 \mathrm{ab}$ & 0.33 & 0.67 & $5.2 \mathrm{ab}$ & $5.6 \mathrm{~d}$ \\
\hline $\mathrm{CCC}$ & NT & $5.7 \mathrm{a}$ & 0.67 & 0.67 & $4.9 \mathrm{c}$ & $8.2 \mathrm{bc}$ \\
\hline $\mathrm{CSC}$ & PT & $5.1 \mathrm{ab}$ & 0.67 & 1.00 & $5.2 \mathrm{ab}$ & $5.6 \mathrm{~d}$ \\
\hline CSC & MT & $4.5 \mathrm{ab}$ & 0.33 & 1.00 & $5.1 \mathrm{bc}$ & $6.2 \mathrm{~d}$ \\
\hline CSC & NT & NA & 0.00 & 0.00 & $5.6 \mathrm{a}$ & $8.4 \mathrm{bc}$ \\
\hline $\mathrm{COH}$ & PT & $4.4 \mathrm{~b}$ & 0.33 & 0.67 & $5.3 \mathrm{ab}$ & $7.7 \mathrm{c}$ \\
\hline $\mathrm{COH}$ & MT & $4.2 \mathrm{~b}$ & 0.00 & 1.00 & $5.3 \mathrm{ab}$ & $9.3 \mathrm{~b}$ \\
\hline $\mathrm{COH}$ & NT & $5.3 \mathrm{ab}$ & 0.67 & 1.00 & $5.3 \mathrm{ab}$ & $12.7 \mathrm{a}$ \\
\hline
\end{tabular}

u Means followed by the same letter are not statistically different according to Fisher's protected least significant difference at $P<0.05$.

${ }^{v}$ Proportion of root samples harboring population of phlD-containing pseudomonads at the abundance levels indicated.

${ }^{w}$ Rotation sequences included continuous corn (CCC), corn-soybean-corn (CSC), and corn-oat-hay (COH).

x Tillage practices included conventional plow tillage (PT), chisel tillage (moderate tillage [MT]), and no tillage (NT).

y Mean population size $(n=3)$ of phlD-containing pseudomonads on colonized plants expressed as log CFU per gram of fresh weight.

${ }^{\mathrm{z}}$ Missing data point $(n=2)$.
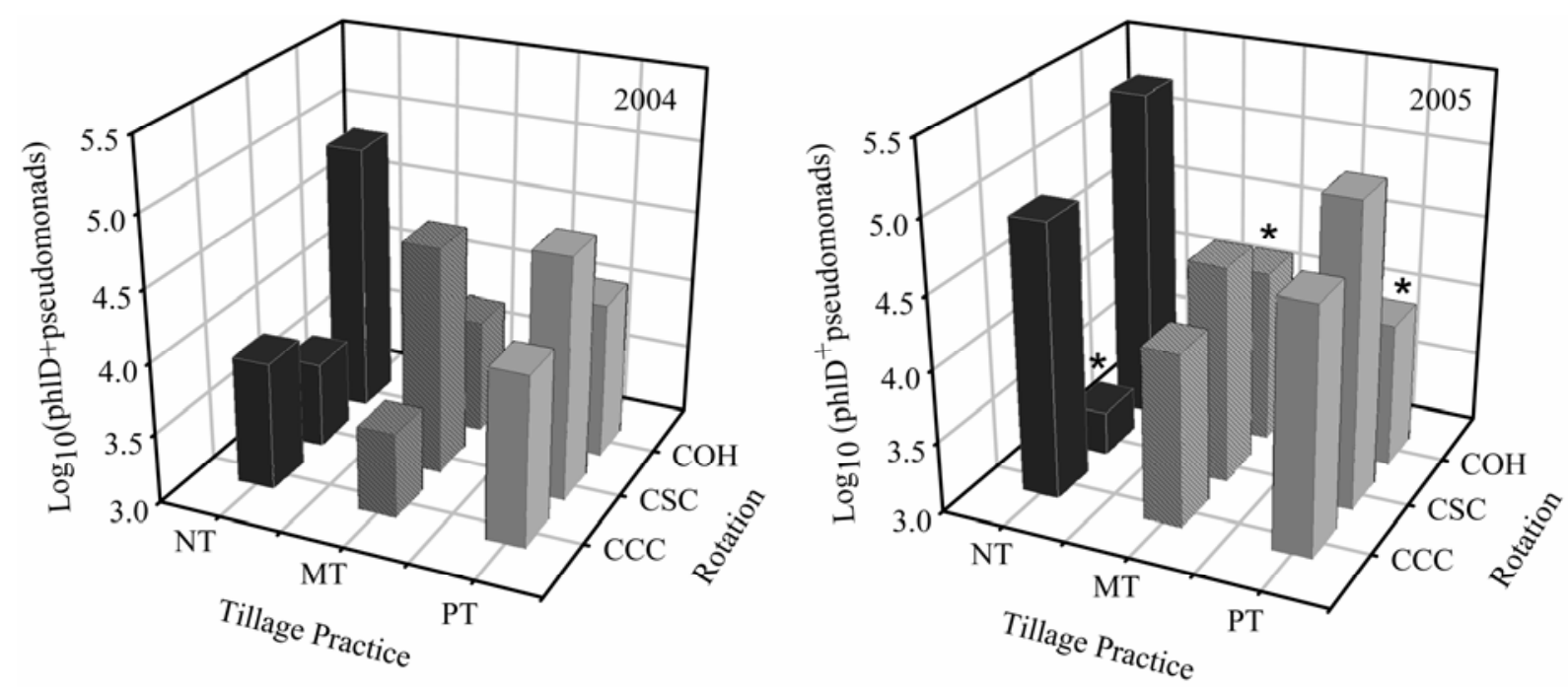

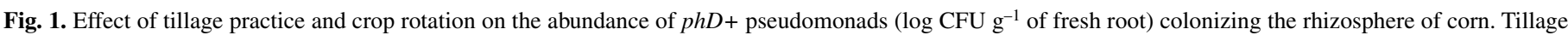

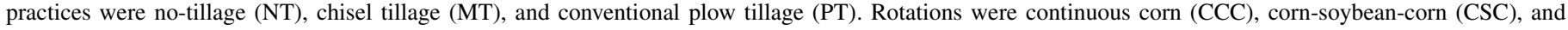

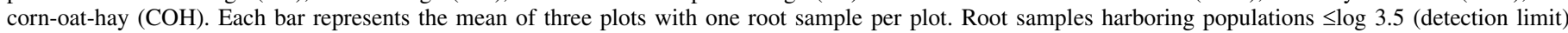

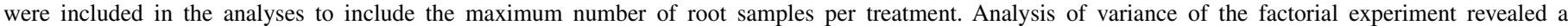

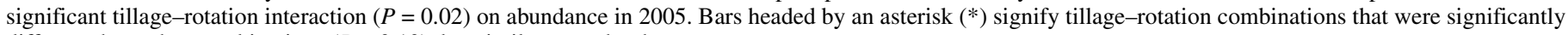
different than other combinations $(P<0.10)$, but similar to each other. 
bean was most strongly associated with soil $\mathrm{pH}$ (Table 3). Soil $\mathrm{pH}$ was lowest $(P<0.05)$ in continuous corn plots for both years $(\mathrm{pH}$ $=6.2$ and 5.9, 2004 and 2005, respectively), an observation that may reflect the acidifying affects of the annual application of nitrogen fertilizer. Consistent between years, abundance of $p h l D+$ bacteria was positively $(P<0.05)$ correlated with soil $\mathrm{pH}, \mathrm{Ca}$, and $\mathrm{Mg}$ concentration in $\mathrm{CC}$ plots. In this rotation treatment, there was a strong, positive correlation between soil $\mathrm{pH}$ and soil $\mathrm{C}$ content in $2004(r=0.98, P=0.01)$, but a negative correlation $(r$ $=-0.84, P=0.007)$ in 2005. The relationship between abundance and soil $\mathrm{C}$ mirrored the direction of these relationships for the $\mathrm{CC}$ treatment. In SS plots, soil $\mathrm{pH}$ and $\mathrm{Ca}$ content were negatively correlated $(P<0.05)$ to abundance and, unlike the CC plots, soil $\mathrm{pH}$ was negatively correlated to soil $\mathrm{C}(r=-0.89, P=0.1)$ and abundance was not related significantly $(P>0.25)$ to soil $\mathrm{C}$ content. Although average abundance of $p h l D+$ bacteria mirrored patterns in VM content of soils at the time of sampling (Table 2), there were no consistent correlations between VM and abundance of $p h l D+$ bacteria in any of the rotation treatments. There were no consistent or apparent correlations $(P>0.2)$ between soil $\mathrm{pH}$ or the concentration of any soil mineral measured and rhizosphere abundance of total pseudomonads for any rotation treatment $(P>$ $0.15)$.

Rhizosphere abundance of phlD+ pseudomonads in the SCC plots. The abundance and incidence of phlD + Pseudomonas spp. in the rhizosphere of sweet corn grown in compost-amended soils were determined (Table 4). Bacterial population data for all three cultivars were combined for each compost treatment because cultivar was not observed to influence the abundance nor the incidence of $p h l D+$ bacteria $(P>0.25)$ in the rhizosphere. Over all cultivars, the rhizosphere abundance of phlD+ pseudomonads was observed to increase only marginally and nonsignificantly in soils amended with compost $(P>0.25)$.

Although compost additions to the SCC plot only marginally influenced rhizosphere populations of phlD+ bacteria, soil fertility was significantly altered $(P<0.01)$ by the amendments. Nonamended soils contained, on average, 0.1 and $1 \%$ soil $\mathrm{N}$ and $\mathrm{C}$, respectively, and $146 \mu \mathrm{g}$ of P, $229 \mu \mathrm{g}$ of K, 1,244 $\mu \mathrm{g}$ of $\mathrm{Ca}$, $266 \mu \mathrm{g}$ of Mg, $724 \mu \mathrm{g}$ of Al, $1.5 \mu \mathrm{g}$ of B, $3.2 \mu \mathrm{g}$ of Cu, $234 \mu \mathrm{g}$ of $\mathrm{Fe}, 261 \mu \mathrm{g}$ of $\mathrm{Mn}, 30 \mu \mathrm{g}$ of $\mathrm{Na}, 5 \mu \mathrm{g}$ of $\mathrm{Zn}$, and $44 \mu \mathrm{g}$ of S per gram of soil. Application of the high rate of compost $\left(12 \mathrm{tha}^{-1}\right)$, increased $\mathrm{P}, \mathrm{K}, \mathrm{S}, \mathrm{Ca}$, and $\mathrm{Mg}$ concentrations 1.4- to 2.4-fold, whereas the concentration of micronutrients $\mathrm{B}, \mathrm{Na}, \mathrm{Zn}$, and $\mathrm{Cu}$ increased 2- to 4-fold in the soil solution. Carbon contents averaged 2 and $4 \%$ in soils amended with the low $\left(6 \mathrm{tha}^{-1}\right)$ and high rates of compost, respectively. Soil $\mathrm{pH}$ was higher $(P<0.05)$ in plots amended with the high rate of compost ( $\mathrm{pH}$ 7.2) compared with nonamended plots ( $\mathrm{pH} \mathrm{6.9)}$ and the plot-to-plot variation in soil $\mathrm{pH}$ in the compost-amended soils was relatively small compared with nonamended soils, with the coefficient of variation being 0.8 and $3 \%$, respectively.

As documented in the ROTA study, phlD+ populations were significantly correlated to $\mathrm{pH}$ (Table 5) in nonamended soils. Soil $\mathrm{pH}$ was negatively correlated $(r=-0.97, P=0.002)$ with the

TABLE 2. Effect of rotation sequence on measures of plant health and native populations of phlD+ pseudomonads in the rhizosphere of corn and soybean in the no-till rotation plots

\begin{tabular}{|c|c|c|c|c|c|c|c|c|c|}
\hline \multirow[b]{2}{*}{ Year, crop } & \multirow[b]{2}{*}{ Rotation $^{w}$} & \multicolumn{2}{|c|}{ Abundance ${ }^{\mathrm{t}, \mathrm{u}}$} & \multirow[b]{2}{*}{$\operatorname{phlD}+(\%)^{\mathrm{x}, \mathrm{u}}$} & \multicolumn{2}{|c|}{ Incidence $^{\mathrm{v}}$} & \multirow[b]{2}{*}{$\mathrm{VM}(\%)^{\mathrm{y}, \mathrm{u}}$} & \multirow[b]{2}{*}{ Stand (plants $\left.\mathrm{m}^{-1}\right)^{\mathrm{z}}$} & \multirow[b]{2}{*}{ Yield $\left(\mathrm{tha}^{-1}\right)^{\mathrm{z}}$} \\
\hline & & Total Ps & phlD+ & & $\geq \log 4.5$ & $\geq \log 3.5$ & & & \\
\hline \multicolumn{10}{|l|}{2004} \\
\hline Corn & $\mathrm{CC}$ & $6.1 \mathrm{a}$ & $4.57 \mathrm{a}$ & $17.4 \mathrm{~b}$ & 0.50 & 0.87 & $22.5 \mathrm{a}$ & $2.6 \mathrm{~b}$ & $2.3 \mathrm{~b}$ \\
\hline Soy & $\mathrm{CS}$ & $5.5 \mathrm{a}$ & $5.09 \mathrm{a}$ & $71.4 \mathrm{a}$ & 0.50 & 0.75 & $21.7 \mathrm{~b}$ & $13.8 \mathrm{~B}$ & $1.8 \mathrm{~A}$ \\
\hline Soy & SS & $5.9 \mathrm{a}$ & $4.52 \mathrm{a}$ & $15.1 \mathrm{~b}$ & 0.38 & 0.87 & $19.4 \mathrm{ab}$ & $15.5 \mathrm{~A}$ & $1.6 \mathrm{~A}$ \\
\hline \multicolumn{10}{|l|}{2005} \\
\hline Soy & SS & $6.9 \mathrm{a}$ & $4.57 \mathrm{a}$ & $11.3 \mathrm{a}$ & 0.56 & 0.75 & $10.4 \mathrm{~b}$ & $13.2 \mathrm{~A}$ & $1.0 \mathrm{~A}$ \\
\hline
\end{tabular}

${ }^{\mathrm{t}}$ Mean population size ( $n=6$ to 8 ) of total pseudomonads (Ps) and phlD-containing pseudomonads on colonized plants expressed as log CFU per gram of fresh weight.

"Means followed by the same letter are not statistically different among rotation treatments according to Fisher's protected least significant difference (LSD) at $P$ $<0.05$.

${ }^{v}$ Proportion of root samples harboring population of phlD-containing pseudomonads at the abundance levels indicated.

${ }^{\text {w }}$ Rotation sequences include continuous corn (CC), corn following soybean (SC), soybean following corn (CS), and continuous soybean (SS).

${ }^{x}$ Percentage of Pseudomonas population harboring phlD.

y Volumetric moisture (VM) content of bulk soil retrieved from plots at time of plant sampling for assessment of root colonization.

${ }^{\mathrm{z}}$ Means ( $n=4$ plots) followed by the same letter are not statistically different within a crop according to Fisher's protected LSD at $P<0.05$.

TABLE 3. Correlations between soil properties and abundance of phlD+Pseudomonas populations in the rhizosphere of corn and soybean roots in the no-till rotation plots ${ }^{y}$

\begin{tabular}{|c|c|c|c|c|c|c|c|}
\hline Year, crop & Rotation $^{2}$ & $\mathrm{pH}$ & $\mathrm{C}(\%)$ & $\mathrm{N}(\%)$ & $\mathrm{Al}$ (ppm) & $\mathrm{Ca}(\mathrm{ppm})$ & $\mathrm{Mg}(\mathrm{ppm})$ \\
\hline \multicolumn{8}{|l|}{2004} \\
\hline Corn & $\mathrm{SC}$ & -0.93 & -0.26 & 0.68 & 0.90 & -0.89 & -0.87 \\
\hline Soy & SS & -0.72 & 0.50 & 0.77 & 0.65 & -0.78 & -0.21 \\
\hline \multicolumn{8}{|l|}{2005} \\
\hline Corn & $\mathrm{CC}$ & 0.86 & -0.81 & -0.74 & -0.73 & 0.63 & 0.65 \\
\hline Corn & $\mathrm{SC}$ & -0.10 & 0.58 & 0.56 & 0.57 & 0.17 & 0.00 \\
\hline
\end{tabular}

y Population size of phlD-containing pseudomonads on colonized plants expressed as log CFU per gram of fresh weight. Data are Pearson's correlation coefficient $(n=4)$. Coefficients in bold signify significant correlations $(P<0.1)$, and coefficients in italics are not significant $(P>0.1)$.

${ }^{\mathrm{z}}$ Rotation sequences included continuous corn (CC), corn following soybean (SC), soybean following corn (CS), and continuous soybean (SS). 
carbon content of the soils amended with the high rate of compost. In contrast, there was a positive correlation between $\mathrm{pH}$ and amount of total $\mathrm{C}$ in nonamended $(r=0.99, P=0.0001)$ and lowrate-amended ( $r=0.81, P=0.05)$ soils. The basic ions found to be correlated to $\mathrm{pH}$ and abundance of $p h l D+$ bacteria in the ROTA study were significantly ( $P=0.02$ to 0.03 ) altered by compost additions. There was a significant, positive correlation between $\mathrm{Ca}$ content and rhizosphere abundance of phlD+ bacteria in plots amended with the high rate of compost. In contrast, there were no significant correlations between abundance of total pseudomonads and $\mathrm{pH}$ or any other soil chemical measured $(P>$ $0.25)$, suggesting that $p h l D+$ subpopulations were relatively more sensitive to variations in soil chemistry in this study.

Rhizosphere abundance of phlD+ pseudomonads in the STT. Chemical seed treatments affected the abundance of phlD+ Pseudomonas spp. in the rhizosphere of young field corn (Table 6). Corn seed pretreated with Maxim and Lorsban gave rise to roots that were more abundantly colonized by native populations of phlD-containing bacteria in four of five field trials. The difference was significant overall $(P<0.08)$, but site-to-site variation in the relative abundance of phlD was even more significant $(P<$ 0.01 ). The incidence of roots colonized at $>\log 4.5$ cells per gram fresh weight also was observed to be higher in the treated plots. In contrast, the total number of pseudomonads did not respond consistently to the seed treatment.

Associations between average rhizosphere abundance of phlD pseudomonads and average stand and yield across rotation and tillage treatments. Crop stand is inversely related to damping-off disease pressure and, when significant variations in stand were noted, the relative abundance of $p h l D$ in the rhizosphere of colonized corn and soybean also differed in no-till cropping systems. In the LTT experiment (Table 1), few significant differences in stand were observed. Most notably, corn grown continuously (CCC) under no-tillage had significantly lower stands than corn grown in 2- and 3- year (CSC and $\mathrm{COH}$, respectively) rotations $(P<0.05)$ in 2005 . The average abundance of phlD on colonized plants was also higher in the CCC no-till plots compared with the CSC and $\mathrm{COH}$ no-till plots (log 5.7 versus $\log 3.4$ and $\log 5.3$, respectively). Likewise, in the ROTA experiment (Table 2), CC had significantly lower stands than rotated corn in both years $(P<0.05$ for each). Continuously cropped corn also tended to have larger populations of phlD+ pseudomonads in the rhizosphere of colonized plants, in terms of average abundance (log 4.6 versus $\log 4.5$ in 2004, and $\log 5.0$ versus 4.8 in 2005) and percentage of cultured pseudomonads (17.4 versus 6.4 in 2004 and 28.7 versus 14.0 in 2005) (Table 2). Interestingly, soybean stands generally were lower following corn, indicating that elevated soil moisture levels and lower soil temperatures (data not shown) caused by the presence of corn residue probably led to increased damping-off disease pressure in the rotated compared with continuous plots. In 2004, the soybean plots that had significantly lower stands $(P<0.01)$ also tended to have larger populations of phlD+ pseudomonads, both in terms of average abundance (log 5.1 versus $\log 4.5)$ and percentage of cultured pseudomonads (71.4 versus 15.1). This pattern was not observed in 2005, when differences in soybean stands were minimal (i.e., $2 \%$ reduction in 2005 compared with $12 \%$ reduction in 2004).

In the tilled plots of the LTT, SCC, and STT experiments, associations between stand and phlD populations on colonized plants varied. In the LTT, tillage did not consistently alter corn stands or phlD populations relative to the no-till treatments (Table 1). In the SCC experiment (Table 4), stands were lowest in the plots that did not receive the compost amendments $(P<0.05)$.

TABLE 4. Effect of compost applications on abundance and incidence of phlD-containing pseudomonads and plant health in tilled sweet corn plots ${ }^{\mathrm{u}}$

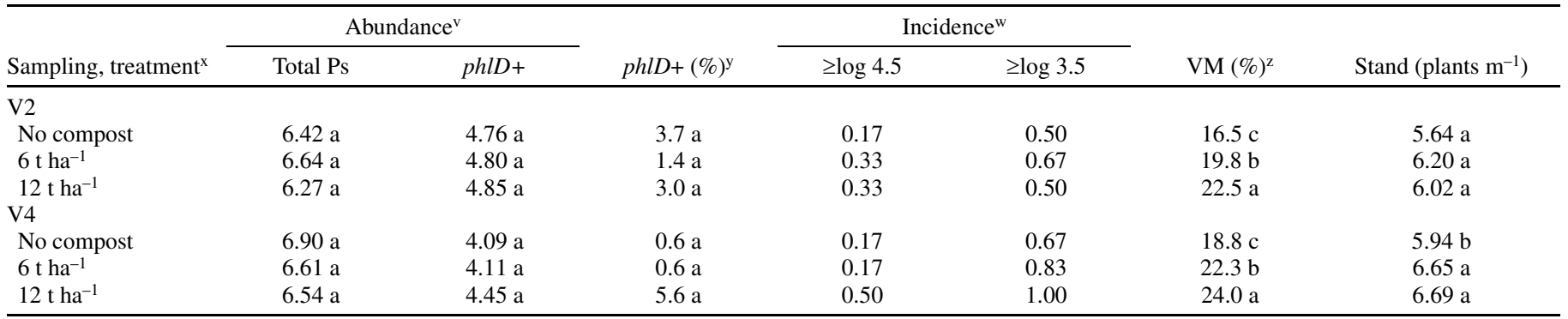

u Compost was applied to plots 2 weeks prior to planting in 2004. Means followed by the same letter are not significantly different at $P<0.1$.

${ }^{v}$ Mean population size $(n=6)$ of total pseudomonads (Ps) and phlD-containing pseudomonads on colonized plants expressed as log CFU per gram of fresh weight.

${ }^{w}$ Proportion of root samples harboring population of phlD-containing pseudomonads at the abundance levels indicated.

${ }^{x}$ Plants were sampled at the early vegetative stages V2 and V4. Data sets included values for cvs. Ambrosia and Bodacious at V2 and Ambrosia and Kandy Korn at V4 for each compost treatment $(n=6)$.

y Percentage of Pseudomonas population harboring phlD.

${ }^{\mathrm{z}}$ Volumetric moisture $(\mathrm{VM})$ content of bulk soil retrieved from plots $(n=6)$ at time of plant sampling for assessment of root colonization.

TABLE 5. Correlations between soil properties and rhizosphere abundance of phlD+ pseudomonads associated with sweet corn roots in conventionally tilled plots ${ }^{\mathrm{y}}$

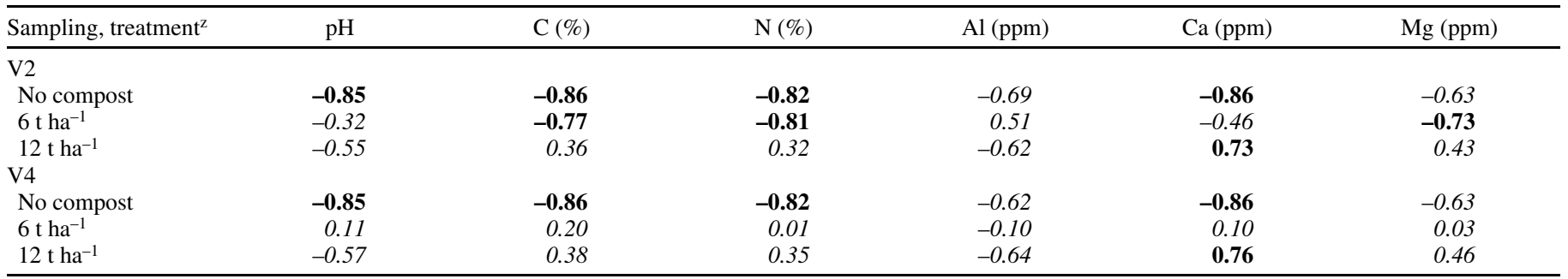

y Population size of phlD-containing pseudomonads on colonized plants expressed as log CFU per gram of fresh weight. Data are Pearson's correlation coefficient $(n=6)$. Coefficients in bold indicate significant correlations $(P<0.05)$ and coefficients in italics are not significant $(P>0.2)$.

${ }^{z}$ Plants were sampled at the early vegetative stages V2 and V4. Data sets included values for cvs. Ambrosia and Bodacious at V2 and Ambrosia and Kandy Korn at V4 for each compost treatment $(n=6)$. 
The rhizosphere abundance of phlD+ pseudomonads tended to be lower in the nonamended plots during the early stages of growth and was largest in the most heavily amended plots, but these trends were not significant. In the STT experiment, chemical seed treatments led to more abundant rhizosphere populations of phlD and increased stands at four of the five sites (Table 6). However, the same patterns in both response variables were observed only at the Clarke, Crawford, and Darke County sites. Nonetheless, both the relative abundance of phlD and crop stands appeared to be higher in the plots receiving chemical seed treatments $(P<$ 0.03 and 0.11 , respectively).

With regards to crop productivity, the associations between average rhizosphere abundance of phlD on colonized plants and average corn yields varied by treatment and location. At the two sites located on the OARDC farm in Wayne County, there appeared to be an inverse association between mean rhizosphere abundance of phlD on colonized plants and corn yields when significant differences in yields were observed. Differences in corn yields generally were consistent with the hypothesis that rotation increases yields. In the LTT (Table 1), the 3-year $(\mathrm{COH})$ rotations resulted in higher yields than corn grown continuously in the tilled (PT and MT) plots in 2004, and regardless of tillage treatment in 2005. Inversely, the average relative abundance of phlD on colonized plants tended to be higher where yields were significantly lower, regardless of the tillage regime applied; however, the variation in $p h l D$ abundances were not significant in the individual comparisons. Additionally, the $\mathrm{COH}$ rotation yielded more than the corresponding CSC rotation plots in 2005 and, again, the mean population size of phlD varied inversely with yield in the MT and PT plots. In the ROTA experiment (Table 2), the inverse association was clearly evident. The 2-year rotation with soybean resulted in higher corn yields compared with continuous cropping in both years $(P<0.05$ for both comparisons), and the proportion of pseudomonads containing the phlD gene tended to be higher on the lower-yielding corn. In contrast, there was a positive relationship between the abundance of $p h l D+$ pseudomonads and yield at the majority of sites examined in the STT experiment, where fungicide-treated seed generally yielded more than untreated seed (Table 6). This pattern was significant over the entire experiment $(P<0.04$ for both variables $)$, and it was observed at all sites, except the one in Wyandot County. At this site, the rhizosphere abundance of phlD was uniformly high in both treatments and the yields were also higher than at any other site. These sites also differed from the OARDC sites in that all plots received more fertilizer prior to planting.
Statistical correlations between crop health measures and rhizosphere abundance of phlD+ pseudomonads within rotation treatments. Comparisons of mean estimates of phlD populations sizes and plant stand and yield between rotation treatments (Tables 1 and 2) hinted at quantitative relationships between the level of $p h l D$ colonization and measures of crop health. Because rotation sequence tended to differentially influence both $p h l D$ abundance and, in several cases, significantly influence plant stand and yield, correlation analyses were performed. Multiple measurements obtained from each rotation treatment separately were used to better estimate the rhizosphere abundance of DAPG producers and to better resolve the direction of the relationships between the abundance of $p h l D+$ pseudomonads and crop health measures. The results for the LTT and ROTA sites revealed three interesting patterns (Fig. 2). First, the correlations between rhizosphere abundance of phlD+ Pseudomonas spp. and crop stand and yield were more positive in plots experiencing continuous cropping compared with rotated cropping. Overall, this pattern was observed in 10 of the 12 paired comparisons of correlation coefficients calculated for the LTT and ROTA experiments. Second, in corn, cropping history apparently affected the direction of the relationships. In CC, positive correlations were found in seven of eight instances, three of which were clearly significant $(P<0.05$ for each). However, in rotated corn, five of eight correlations were observed to be negative, particularly with regards to the yields measured in $2005(P<0.1$ for each). Third, in soybean, the measured associations between phlD abundance and crop stand and yield tended to be negative. In ROTA, seven of eight measured correlations were negative, and two were significantly negative $(P<0.10)$. In the SCC experiment, compost applications led to greater stands which were positively correlated with the rhizosphere abundance of $p h l D$, but the observed relationship was not statistically significant. Last, in the STT experiments, the abundance of $p h l D+$ pseudomonads was positively correlated with overall crop stand $(P<0.03)$ and yield $(P<0.09)$. Although positive correlations in the STT generally were observed regardless of site or treatment, only the correlation with stand in fungicide-treated plots was significant $(P<0.04)$ when the data set was split into subsets for analyses.

\section{DISCUSSION}

Previously, multivariate analyses have shown that farm management practices can influence microbial community structure overall. For example, Spedding et al. (40) showed that

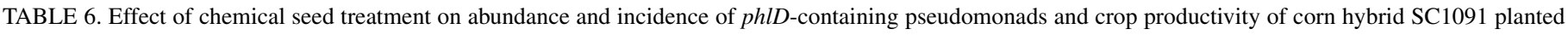
throughout Ohiow

\begin{tabular}{|c|c|c|c|c|c|c|c|c|}
\hline \multirow[b]{2}{*}{ Site } & \multirow[b]{2}{*}{ Treatment } & \multicolumn{2}{|c|}{ Abundance $^{\mathrm{x}}$} & \multirow[b]{2}{*}{$p h l D+(\%)^{\mathrm{z}}$} & \multicolumn{2}{|c|}{ Incidence ${ }^{y}$} & \multirow[b]{2}{*}{ Stand (plants $\mathrm{m}^{-1}$ ) } & \multirow[b]{2}{*}{ Yield $\left(\mathrm{t} \mathrm{ha}^{-1}\right)$} \\
\hline & & Total Ps & phlD+ & & $\geq \log 4.5$ & $\geq \log 3.5$ & & \\
\hline \multirow[t]{2}{*}{ Clark } & Treated & 6.43 & 4.26 & 2.7 & 0.75 & 0.75 & 6.05 & 11.8 \\
\hline & Untreated & 6.40 & 3.86 & 3.5 & 0.25 & 0.75 & 5.81 & 10.5 \\
\hline \multirow[t]{2}{*}{ Crawford } & Treated & 5.13 & 5.40 & 56.5 & 1.00 & 1.00 & 6.38 & 10.1 \\
\hline & Untreated & 5.54 & 5.13 & 31.6 & 1.00 & 1.00 & 5.82 & 9.7 \\
\hline \multirow[t]{2}{*}{ Darke } & Treated & 5.72 & 5.17 & 17.5 & 1.00 & 1.00 & 6.29 & 11.5 \\
\hline & Untreated & 5.20 & 4.65 & 38.5 & 1.00 & 1.00 & 6.17 & 10.7 \\
\hline \multirow[t]{2}{*}{ Wood } & Treated & 5.77 & 4.68 & 25.5 & 0.67 & 1.00 & 5.83 & 12.2 \\
\hline & Untreated & 5.08 & 4.00 & 12.7 & 0.67 & 1.00 & 5.92 & 11.8 \\
\hline \multirow[t]{2}{*}{ Wyandot } & Treated & 6.27 & 5.53 & 14.1 & 1.00 & 1.00 & 6.25 & 12.5 \\
\hline & Untreated & 6.26 & 5.54 & 23.4 & 1.00 & 1.00 & 6.00 & 12.0 \\
\hline \multirow[t]{2}{*}{ All 5} & Treated & $5.81 \mathrm{a}$ & $5.03 \mathrm{a}$ & $25.3 \mathrm{a}$ & 0.88 & 0.95 & $6.09 \mathrm{a}$ & $11.6 \mathrm{a}$ \\
\hline & Untreated & $5.69 \mathrm{a}$ & $4.67 \mathrm{~b}$ & $22.5 \mathrm{a}$ & 0.78 & 0.95 & $5.91 \mathrm{~b}$ & $10.8 \mathrm{~b}$ \\
\hline
\end{tabular}

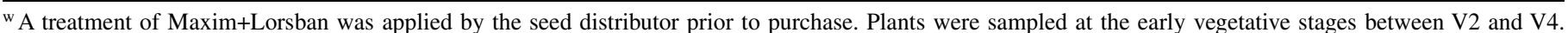
Means for the same site followed by the same letter are not significantly different at $P>0.1$ for each paired comparison.

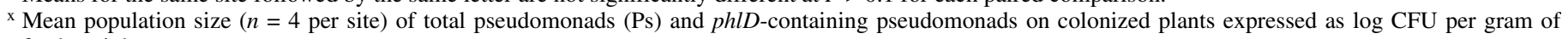
fresh weight.

y Proportion of root samples harboring population of phlD-containing pseudomonads at the abundance levels indicated.

z Percentage of Pseudomonas population harboring phlD. 
tillage and seasonal variation can alter soil microbial community structure as measured by phospholipid fatty acid analyses. Changes in soil populations might reasonably be expected to alter rhizosphere community structure to some degree and, indeed, crop rotations have been shown to alter bacterial community structure in the rhizosphere of corn (1). Diverse soil and root-associated microbial populations affect crop health, either positively or negatively (13). However, to understand the contributions of each population to crop health under diverse growing conditions is a formidable task. Here, in a series of field experiments, we found that farm management practices measurably affected the rhizosphere incidence and relative abundance of phlD+ pseudomonads in subtle, complex, but quite reproducible ways. Because the population responses were typically less distinct than the crop health effects influenced by the farm management practices examined, native populations of phlD+ pseudomonads predictably account for only a small portion of the variance in crop health, at least in corn and soybean.

In this study, the responses of the native rhizosphere Pseudomonas spp. and phlD+ subpopulations thereof to farm practices was examined. In most individual experiments, the magnitude of variation in the abundance of phlD was small and not statistically significant. Clearly, individual sample sizes for each experimental treatment were quite small, and this greatly limited the statistical power of each analysis. Nonetheless, we noted recurring patterns of responses to farm management across multiple field sites and across multiple years. For example, corn grown in 2-year rotations had fewer phlD+ pseudomonads in their rhizosphere than corn grown continuously. This response was observed in both years in the untilled plots of both the LTT (Table 1) and ROTA (Table 2) experiments. Likewise, at four of five locations, roots developing from untreated seed harbored fewer phlD+ than roots developing from seed pretreated with a standard fungicide and insecticide mix (Table 6). We also identified a complex interaction between cropping sequence and tillage that led to reproducible patterns of rhizosphere abundance of phlD (Fig. 1). The presence of the interaction at this site indicates that the effect of tillage is dependent on cropping sequence. For example, rhizosphere populations of $p h l D+$ pseudomonads were relatively invariant to tillage practice in continuously cropped corn plots, whereas abundance of these beneficial bacteria was lower on corn roots following a soybean season in undisturbed versus disturbed soils.

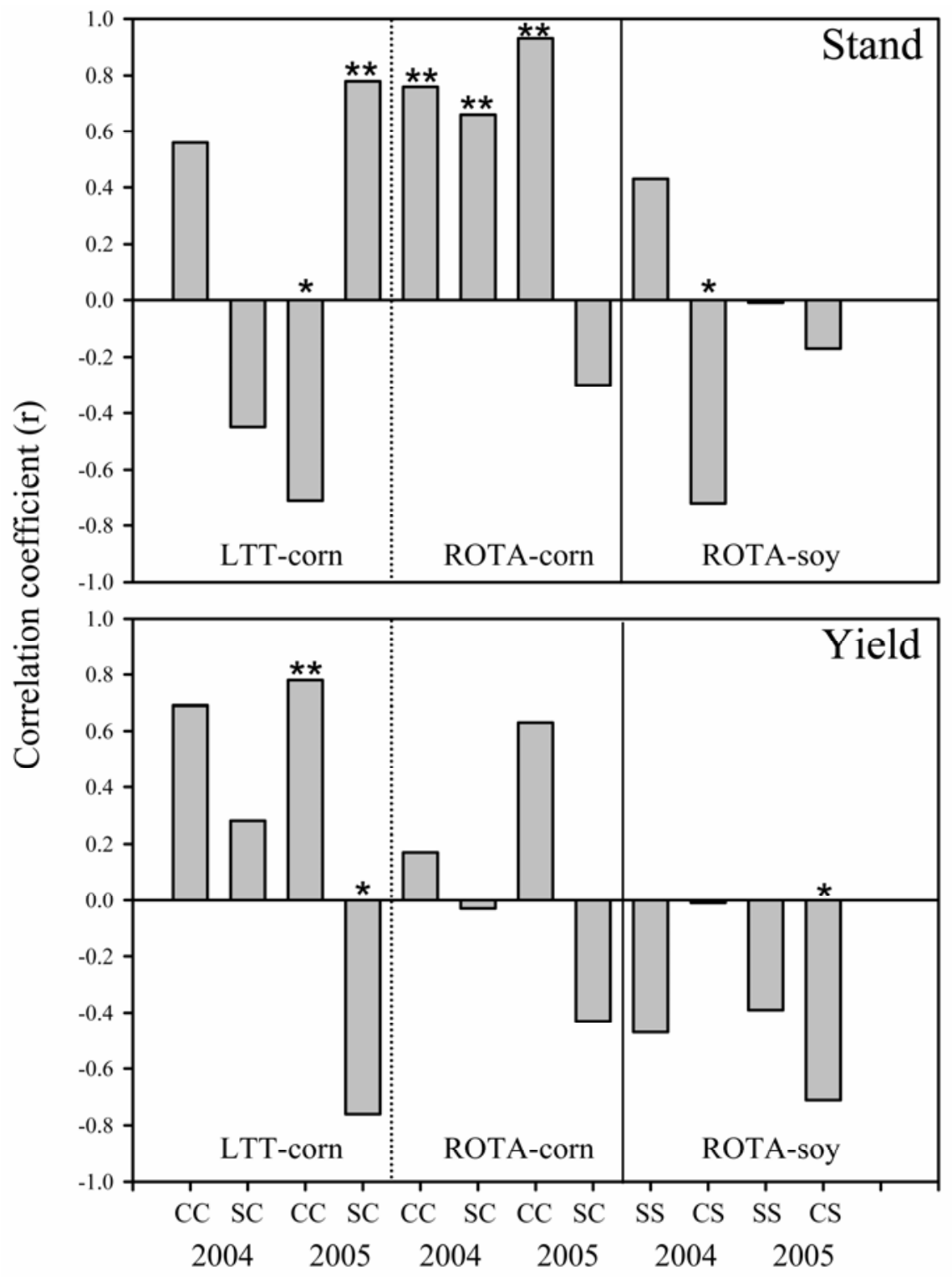

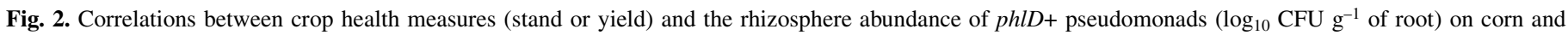

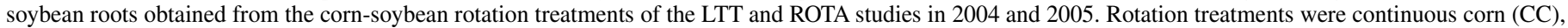

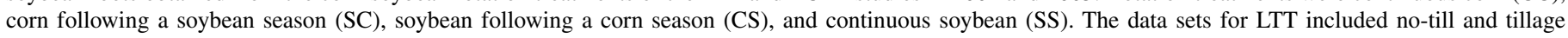
treatments for each rotation. Significant correlations for individual rotation treatments are noted at $P<0.05(* *)$ and $P<0.10(*)$. 
The magnitude of the observed responses was generally on the order of a twofold variation in relative abundance. The rhizosphere abundance of DAPG producers previously was shown to vary by plant species and soil source, whether grown in the greenhouse $(4,9,36)$ or the field $(28)$. In all of those studies, the magnitude of the noted variations was similar to that noted here in response to farm management practices. Similar subtle variations in the abundance of diverse soil microbes, including culturable Pseudomonas populations, have been observed in response to crop rotations, and those differences have been linked to variation in soilborne diseases of potato $(19,21)$. The reproducibility of the observed responses across sites and years indicates that the choices made by farm managers will affect the ability of native biocontrol populations (such as DAPG-producing pseudomonads) to successfully colonize crop roots and raises the question of how those choices determine crop responses to native and applied biocontrol agents.

Much practical experience has shown that tillage, rotations, organic amendments, and chemical seed treatments can minimize soilborne disease pressure and, thereby, increase stands and yields of corn and soybean (15). In this study, these practices significantly increased overall stands or yields of corn in the LTT, ROTA, SCC, and STT plots. In contrast to the more subtle responses of $p h l D+$ pseudomonads described above, crop responses to rotation, organic amendments, and chemical seed treatment generally were significant at the individual trial level (Tables 1, 2, 4, and 6). Therefore, crop health, measured as both stand and yield, was more predictably responsive to farm management practices than rhizosphere populations of phlD+ pseudomonads. Therefore, do native populations of DAPG-producing Pseudomonas spp. significantly contribute to disease suppression? The data presented here and in previous studies indicate that the answer is yes, but the quantitative relationship can vary significantly in a context-dependent way. For example, we found that rhizosphere abundance was greater in treatments where damping-off disease pressure was greatest in the ROTA plots (Table 2). Such a result is consistent with previous work indicating that wheat root infections by the take-all fungus harbored more DAPG producers than those not infected (29). In contrast, previous studies comparing plants grown in soils varying in their disease-suppressive potential indicated that the relative abundance of phlD+ pseudomonads generally was greater in soil suppressive to take-all, a phenomenon arising from variation in cropping history $(9,34)$. Likewise, some treatments that reduced damping-off and generally improved crop health in the SCC (Table 3) and STT plots (Table 6) also were observed to increase the abundance of native phlD+ pseudomonads. Thus, farm management can have a profound effect on the relationship between rhizosphere colonization by native populations of DAPG-producing pseudomonads and crop health. Correlation analyses were performed to determine the frequency with which native populations of DAPG producers might positively contribute to crop health. Interestingly, the correlations between the rhizosphere abundance of phlD and crop health measures (i.e., stand and yield) were relatively consistent within individual treatments but differed markedly by crop.

For corn, positive correlations between rhizosphere abundance of phlD and crop health measures generally were observed in individual treatments of the different experiments. These patterns were observed at multiple sites and multiple years. In both the LTT and ROTA plots, the measured correlations were more frequently positive for continuous corn than rotated corn (Fig. 2), even though the latter treatment generally had higher stands and yields (Tables 1 and 2). The stronger association between the relative abundance of phlD and crop health in plots experiencing more disease pressure may indicate that native populations of DAPG producers increase in response to root damage. Previously, it was noted that phlD+ populations were more abundant in diseased compared with healthy rhizospheres of wheat (29) and expression of the phl genes was elevated in Pythium-infected corn and cucumber (32). However, in the STT experiment, the correlations were stronger for chemically treated seed $(r=0.54, P<$ $0.04)$ than untreated seed ( $r=0.22$, not significant), which generally had lower stands (Table 6). A positive correlation also was observed in the SCC experiment at the V2 but not the V4 sampling (data not shown), which might indicate that DAPG producers are more important at earlier growth stages. Indeed, the abundance per gram fresh weight was higher at the earliest stages of growth in both the SCC and ROTA plot. Such ontogenic variation in corn colonization has been reported previously for corn grown in the greenhouse (33).

In soybean, the correlations between the rhizosphere abundance of phlD and crop health generally were negative in the ROTA experiment (Fig. 2). The broader significance of this relationship is unknown; however, negative correlations also were observed with the stands $(r=-0.58, P<0.02)$ and yields $(r=-0.29$, not significant) of organic soybean fields surveyed in 2005 (data not shown). These negative correlations may indicate that the increases of native $p h l D+$ populations to root infections are not sufficient to suppress subsequent disease development, as seems to be the case in monocot systems noted above. Previously Ramette et al. (36) noted that there was not a consistent relationship between rhizosphere abundance of phlD+ pseudomonads (measured with another method) and suppression of tobacco root rot in greenhouse trials. It may be that native populations of DAPG producers are not able to expand as rapidly in dicot root systems due to differences in rhizosphere structure or chemistry. Further work will be necessary to determine whether the observed associations occur on different crops and different environments, where soilborne pathogens may differ significantly from those affecting corn and soybean in Ohio.

The reason for the inverse associations between crop health and the rhizosphere abundance of phlD on corn and soybean is unclear. However, it is well known that rhizosphere microbial community structure differs significantly between crops and soils (13), and such variation has been noted for DAPG-producing Pseudomonas spp. that colonize field-grown corn and soybean (28). The observed inverse associations may simply indicate that the relative contribution of DAPG producers to crop health varies by plant species. We hypothesize that the relatively infrequent colonization of soybean by native populations probably only occurs following infections, and field trials testing this hypothesis are currently underway (R. Raudales and B. McSpadden Gardener, unpublished results). Additionally, we recently have observed that soybean responded much more positively to inoculation with phlD+ pseudomonads than corn (24,25, unpublished results). Although somewhat incidental, the enhanced inoculant responsiveness of soybean relative to corn further indicates that native populations of DAPG producers do not typically colonize and protect soybean from root pathogens.

With the exception of the CC plots, the correlations between soil $\mathrm{pH}$ and abundance generally were negative (Table 3 and 5). These findings generally contrast with previous work that demonstrated that rhizosphere populations of seed-inoculated Pseudomonas fluorescens F113 on pea ( $\log 6.6 \mathrm{CFU} \mathrm{g^{-1 }}$ of soil) (30) and $P$. fluorescens P5 on sugar beet (log 5.8 CFU plant ${ }^{-1}$ ) (39) were more abundant when grown in soils with higher $\mathrm{pH}(6.4$ and 6.3, respectively) compared with more acidic soils. Interestingly, DAPG is most active against Pythium spp. under acidic conditions, especially with a $\mathrm{pH}<6.5$ (8). Thus, although rhizosphere populations of DAPG producers generally may be lower in acidic soils, their suppressive activity may be greater. This conclusion is supported by our observations that, where $\mathrm{pH}$ was lower in the ROTA plot (i.e., the CC plots), the correlation between crop health and the abundance of phlD was most positive (Fig. 2).

In the SCC experiment, organic amendments significantly increased soil fertility relative to the control plots, while only 
marginally increasing the incidence of root colonization by pseudomonads capable of producing DAPG. Thus, phlD+ bacteria probably did not contribute to a great extent to the measured improvement in crop health and vigor in the SCC. Nonetheless, the observed increases in the nutrient contents of amended soils may have altered DAPG production. Increased levels of minerals, primarily $\mathrm{Zn}$, have been associated with increased production of the DAPG in artificial media (11). However, here, soil Zn was not found to be correlated to rhizosphere abundance. Organic amendments can be used to suppress pathogens (2). However, crop responses reflect complex composition of the substrate (16) and multifactorial interactions among soil components (41). For example, in a 5-year vegetable cropping systems trial in Wisconsin, additions of composted paper mill residuals significantly altered a suite of soil physical and chemical properties (12), which together explained the majority of the variation in the amount of foliar disease experienced by the crops (37). Moreover, with successive annual applications of the amendment, soil conditions changed substantially over time (31) and those changes paralleled the temporal shift from a condition of suppression to enhanced disease. With regard to soilborne pathogens, Pythium spp. frequently are suppressed by the addition of composts; however, other pathogens, such as Rhizoctonia solani, are not $(16,38)$. Recent work by Scheuerell et al. (38) indicated that suppression of Pythium spp. was associated with ammonia volatilization from compost amendments, but that no other single soil chemical factor, such as those measured in this study, could be associated with damping-off disease suppression. Collectively, these findings underscore the challenge of teasing apart the individual effects of compost constituents on both plant health and the microbes that can affect it.

\section{ACKNOWLEDGMENTS}

This work was supported by funds provided the National Research Initiative of the United States Department of Agriculture Cooperative State Research, Education and Extension Service, grant number 200235107-12271 and by the Organic Farming Research Foundation. We thank P. R. Thomison and R. Minyo for assistance with planting, sampling, and data collection of the STT experiment; E. Snavely, D. McIlvaine, and S. Elliot for assistance with organic soybean field sampling; B. Bardall and the Snyder Farm crew for field management assistance related to the ROTA and SCC experiments; J. Durkalski for assistance with data collection from the LTT plots; and E. Horst and J. Mesaros for assistance with sample collection and stand counts.

\section{LITERATURE CITED}

1. Alvey, S., Yang, C. H., Buerkert, A., and Crowley. D. E. 2003. Cereal/legume rotation effects on rhizosphere bacterial community structure in west African soils. Biol. Fertil. Soils 37:73-82.

2. Bailey, K. L., and Lazarovits, G. 2003. Suppressing soilborne diseases with residue management and organic amendments. Soil Tillage Res. 72:169-180.

3. Bangera, M. G., and Thomashow, L. S. 1999. Identification and characterization of a gene cluster for synthesis of the polyketides antibiotic 2,4-diacetylphloroglucinol from Pseudomonas fluorescens 8287. J. Bacteriol. 181:3155-3163.

4. Bergsma-Vlami, M., Prins, M. E., and Raaijmakers, J. M. 2005. Influence of plant species on population dynamics, genotypic diversity and antibiotic production in the rhizosphere by indigenous Pseudomonas spp. FEMS Microbiol. Ecol. 52:59-69.

5. Bockus, W. W., and Shroyer, J. P. 1998. The impact of reduced tillage on soilborne plant pathogens. Annu. Rev. Phytopathol. 36:485-500.

6. Cook, R. J., Weller, D. M., Youssef El-Banna, A., Vakoch, D., and Zhang, H. 2002. Yield responses of direct-seeded wheat to rhizobacteria and fungicide seed treatments. Plant Dis. 86:780-784.

7. Delany, I. R., Walsh, U. F., Ross, I. Fenton, A. M. Corkery, D. M., and O'Gara, F. 2001. Enhancing the biocontrol efficacy of Pseudomonas fluorescens F113 by altering the regulation and production of 2,4diacetylphloroglucinol: Improved Pseudomonas biocontrol inoculants. Plant Soil 232:195-205.
8. de Souza, J., Arnould, C., Deulvot, C., Lemanceau, P., GianinazziPearson, V., and Raaijmakers, J. M 2003. Effect of 2,4-diacetylphloroglucinol on Pythium: cellular responses and variation in sensitivity among propagules and species. Phytopathology 93:966-975.

9. de Souza, J. T., Weller, D. M., and Raaijmakers, J. M. 2003. Frequency, diversity, and activity of 2,4-diacetylphloroglucinol-producing fluorescent Pseudomonas spp. in Dutch take-all decline soils. Phytopathology 93:5463.

10. Dick, W. A., and Van Doren, D., Jr. 1985. Continuous tillage and rotation combinations effects on corn, soybean, and oat yields. Agron. J. 77:459465.

11. Duffy, B. K., and Défago, G. 1999. Environmental factors modulating antibiotic and siderophore biosynthesis by Pseudomonas fluorescens biocontrol strains. Appl. Environ. Microbiol. 65:2429-2438.

12. Foley, B. J., and Cooperband, L. R. 2002. Paper mill residuals and compost effects on soil physical properties, soil fertility, and crop production. J. Environ. Qual. 31:2086-2095.

13. Garbeva, P., van Veen, J. A., and van Elsas, J. D. 2004. Microbial diversity in soil: selection of microbial populations by plant and soil type and implications for disease suppressiveness. Annu. Rev. Phytopathol. 42:243270.

14. Helmke, P. A., and Sparks, D. L. 1996. Lithium, sodium, potassium, rubidium, and cesium. Pages 567-568 in: Methods of Soil Analysis, Part 3-Chemical Methods. Soil Sci. Soc. Am., Madison, WI.

15. Hoeft, R. G., Nafziger, E. D., Johnson, R. R., and Aldrich, S. R. 2000. Modern Corn and Soybean Production. MCSP Publications, Champaign, IL.

16. Hoitink, H., and Boehm, M. 1999. Biocontrol within the context of soil microbial communities: a substrate-dependant phenomenon. Annu. Rev. Phytopathol. 37:427-446.

17. Landa, B. B., Mavrodi, O. V., Raaijmakers, J. M., McSpadden Gardener, B. B., Thomashow, L. S., and Weller, D. M. 2002. Differential ability of genotypes of 2,4-diacetylphloroglucinol-producing Pseudomonas fluorescens strains to colonize the roots of pea plants. Appl. Environ. Microbiol. 68:3226-3237.

18. Landa, B. B., Navas-Cortés, J., and Jiménez-Diaz, J. A. 2004. Integrated management of Fusarium wilt of chickpea with sowing date, host resistance, and biological control. Phytopathology 94:946-960.

19. Larkin, R. P. 2003. Characterization of soil microbial communities under different potato cropping systems by microbial population dynamics, substrate utilization, and fatty acid profiles. Soil Biol. Biochem. 35:14511466.

20. Larkin, R. P., and Fravel, D. R. 2002. Effects of varying environmental conditions on biological control of Fusarium wilt of tomato by nonpathogenic Fusarium spp. Phytopathology 92:1160-1166.

21. Larkin, R. P., and Honeycutt, C. W. 2006. Effects of different 3-year cropping systems on soil microbial communities and Rhizoctonia diseases of potato. Phytopathology 96:68-79.

22. Lewis, J. A., Lumsden, R. D., Millner, P. D., and Keinath, A. P. 1992. Suppression of damping-off of peas and cotton in the field with composted sewage sludge. Crop Prot. 11:260-266.

23. Mavrodi, O. V., McSpadden Gardener, B. B., Mavrodi, D. V., Bonsall, R. F., Weller, D. M., and Thomashow, L. S. 2001. Genetic diversity of phlD from 2,4-diacetylphloro glucinol-producing fluorescent Pseudomonas spp. Phytopathology 91:35-43.

24. McSpadden Gardener, B., Benitez, M.-S., Camp, A., and Zumpetta, C. 2006. Evaluation of a seed treatment containing a phlD+ strain of Pseudomonas fluorescens on organic soybeans, 2005. Biol. Cult. Tests Rep. 21:FC046.

25. McSpadden Gardener, B., Kroon van Diest, C., and Beuerlein, J. 2006. Evaluation of biological seed treatments containing phlD+ strains of Pseudomonas fluorescens on soybeans grown in Ohio, 2005. Biol. Cult. Tests Rep. 21:FC045.

26. McSpadden Gardener, B., Mavrodi, D. V., Thomashow, L. S., and Weller, D. M. 2001. A rapid polymerase chain reaction-based assay characterizing rhizosphere populations of 2,4-diacetylphloroglucinol-producing bacteria. Phytopathology 91:44-54.

27. McSpadden Gardener, B., Schroeder, K., Kalloger, S., Raaijmakers, J., Thomashow, L. S., and Weller, D. M. 2000. Genotypic and phenotypic diversity of phlD-containing Pseudomonas isolated from the rhizosphere of wheat. Appl. Environ. Microbiol. 66:1939-1946.

28. McSpadden Gardener, B. B., Gutierrez, L. J., Joshi, R. Edema, R., and Lutton. E. 2005. Distribution and biocontrol potential of phlD+ pseudomonads in corn and soybean fields. Phytopathology 95:715-724.

29. McSpadden Gardener, B. B., and Weller, D. M. 2001. Changes in populations of rhizosphere bacteria associated with take-all disease of wheat. Appl. Environ. Microbiol. 67:4414-4425.

30. Naseby, D. C., and Lynch, J. M. 1999. Effects of Pseudomonas fluorescens F113 on ecological functions in the pea rhizosphere are dependent on pH. Microb. Ecol. 37:248-256. 
31. Newman, C. M., Rotenberg, D., and Cooperband, L. R. 2005. Paper mill residuals and compost effects on particulate organic matter and related soil functions in a sandy soil. Soil Sci. 170:788-801.

32. Notz, R., Maurhofer, M., Schider-Keel, U., Duffy, B., Haas, D., and Défago, G. 2001. Biotic factors affecting expression of the 2,4diacetylphloroglucinol biosynthesis gene phlA in Pseudomonas fluorescens biocontrol strain CHAO in the rhizosphere. Phytopathology 91:873-881.

33. Picard, C., Di Cello, F., Ventura, M., Fani, R., and Guckert, A. 2000. Frequency and biodiversity of 2,4-diacetylphloroglucinol-producing bacteria isolated from the maize rhizosphere at different stages of plant growth. Appl. Environ. Microbiol. 66:948-955.

34. Raaijmakers, J. M., and Weller, D. M. 1998. Natural plant protection by 2,4-diacetylphloroglucinol-producing Pseudomonas spp. in take-all decline soils. Mol. Plant-Microbe Interact. 11:144-152.

35. Raaijmakers, J. M., Weller, D. M., and Thomashow, L. S. 1997. Frequency of antibiotic-producing Pseudomonas spp. in natural environments. Appl. Environ. Microbiol. 63:881-887.

36. Ramette, A., Moenne-Loccoz, Y., and Défago, G. 2003. Prevalence of fluorescent pseudomonads producing antifungal phloroglucinols and/or hydrogen cyanide in sols naturally suppressive or conducive to tobacco black rot. FEMS Microbiol. Ecol. 44:35-43.

37. Rotenberg, D., Cooperband, L. R., and Stone, A. 2005. Dynamic relationships between soil properties and foliar disease as affected by annual additions of organic amendment to a sandy-soil vegetable production system. Soil Biol. Biochem. 37:1343-1357.

38. Scheuerell, S. J., Sullivan, D. M., and Mahaffee, W. F. 2005. Suppression of seedling damping-off caused by Pythium ultimum, P. irregulare, and Rhizoctonia solani in container media amended with a diverse range of Pacific Northwest compost sources. Phytopathology 95:306-315.

39. Schmidt, C. S., Agostini, F., Simon, A., Whyte, J. Townend, J., Leifert, C., Killham, K., and Mullins, C. 2004. Influence of soil type and pH on the colonization of sugar beet seedlings by antagonistic Pseudomonas and Bacillus strains, and on their control of Pythium damping-off. Eur. J.
Plant Pathol. 110:1025-1046.

40. Spedding, T. A., Hamel, C., Mehys, G. R., and Madramootoo, C. A. 2004. Soil microbial dynamics in maize-growing soil under different tillage and residue management systems. Soil Biol. Biochem. 36:499-512.

41. Stone, A. G., Scheuerell, S. J., and Darby. H. M. 2004. Suppression of soilborne diseases in field agricultural systems: organic matter management, cover cropping, and other cultural practices. Pages 131-177 in: Soil Organic Matter in Sustainable Agriculture. F. Magdoff and R. Weil, eds. CRC Press, Boca Raton, FL.

42. Stone, A. G., Vallad, G. E., Cooperband, L. R., Rotenberg, D., Darby, H. R., James, R. V., Stevenson, W. R., and Goodman, R. M. 2003. Effect of organic amendments on soilborne and foliar diseases in field-grown snap bean and cucumber. Plant Dis. 87:1037-1042.

43. Thomas, G. W. 1996. Soil pH and soil acidity. Pages 475-490 in: Methods of Soil Analysis, Part 3-Chemical Methods. Soil Sci. Soc. Am., Madison, WI.

44. Viebahn, M. Glandorf, D. C. M., Ouwenc, T. W. M., Smit, E., Leeflang, P., Wernars, K., Thomashow, L. S., van Loon, L. C., and Bakker, P. A. H. M. 2003. Repeated introduction of genetically modified Pseudomonas putida WCS358r without intensified effects on the indigenous microflora of field-grown wheat. Appl. Environ. Microbiol. 69:3110-3118.

45. Wang, C., Ramette, A., Punjasamarnwong, P., Zala, M., Natsch, A., Moenne-Loccoz, Y., and Defago, G. 2001. Cosmopolitan distribution of phlD-containing dicotyledonous crop-associated biocontrol pseudomonads of worldwide origin. FEMS Microbiol. Ecol. 37:105-116.

46. Wang, P., Changa, C. M., Watson, M. E., Dick, W. A., Chen, Y., and Hoitink, H. A. J. 2004. Maturity indices for composted dairy and pig manures. Soil Biol. Biochem. 36:767-776.

47. Weller, D. M., Raaijmakers, J. M., McSpadden Gardener, B. B., and Thomashow, L. S. 2002. Microbial populations responsible for specific soil suppressiveness to plant pathogens. Annu. Rev. Phytopathol. 40:309348.

48. Whipps, J. M. 2001. Microbial interactions and biocontrol in the rhizosphere. J. Exp. Bot. 52:487-511. 